\title{
An Empirical Examination of the Impact of Economic Structural Change on Income Inequality: Dynamic Heterogeneous Panel Approach
}

\author{
By Maha Elhini ${ }^{1}$, Rasha Hammam ${ }^{2}$
}

\begin{abstract}
This paper employs structural growth perspective to the analysis of income inequality in 43 countries over the period 2003-2017.The study utilizes two different panel estimation techniques. First, the panel least squares regression examines the relevance of Kuznets effect of the different economic sectors; agriculture, manufacturing and services on income inequality. Second, the pooled mean group (PMG) estimation of dynamic heterogeneous panels gauges the long run impact of the change in sectoral value added as a proxy for structural change on inequality. PMG presents short run adjustments to be country-specific due to the widely different impacts of macroeconomic conditions and vulnerability of each country to income inequality. Empirical findings show that across all countries, sector growth had no to negligible impact on inequality indicating that no signs are evident of Kuznets effect. However, both inflation and unemployment have mixed impacts on inequality in Lower and MiddleIncome countries. Results further reveal that unemployment has a relatively stronger influence on inequality than inflation for Upper-middle income countries, unlike in Lower-middle income countries, where unemployment shows a weaker correlation with inequality than inflation. Results for High-income countries show that the influence between inflation and unemployment are not as big as in Upper middle-income countries.
\end{abstract}

Keywords Income inequality, sectoral value added, inflation, unemployment, heterogeneous panel analysis

\section{Introduction}

The world economy has witnessed a robust growth rate during the last decade, led by growth in emerging market economies besides China's. However, this recent growth, with the exception of that in Latin America, (Lustig, et al. 2013), is associated with rising national-level inequality. Cross-country macro and micro-level data reveal substantial inequality variations within and between countries on the global level. Most Asian and African countries show a growth-equality trade-off (Kanbur, Rhee and Zhuang 2014); (Thorbecke and Duyang 2016). Inequality across world regions varies greatly, for example, in Europe $37 \%$ of total national income was owned by the top $10 \%$ of the earners, while in China $41 \%$ was earned by the top $10 \%$, in Russia $46 \%$, while in USCanada 47\%, (Alvaredo, et al. 2018). On one hand distribution and inequality of income affect a society's ability to convert this income into welfare, but on the other hand inequality does not just affect welfare, but it affects how redistribution impacts incentives. One view is that redistribution reduces rich peoples' incentives to generate additional income, slowing down economic growth, (Herzer and Vollmer 2011). Another argument 
by Alesina and Rodrik (1994), states that in societies where the majority of the population does not have access to productive means, greater demand for redistribution will arise, a conflict which also reduces economic growth. While economic theory advocates a wide range of potential inequality drivers, there is little consensus regarding the most relevant ones. Theoretical and empirical literature reveal that economic growth is the most traditional macroeconomic determinant of inequality, while others have advocated the impact of globalisation on world competition, both views show unsatisfactory results and contradicting stories. It is undoubtful however, that inequality is the final result of the whole economic process incorporating all economic sectors at play. Hence, the concern on the part of policymakers, academics and individuals over rising inequality is, its possible dampening effect on sustainable economic growth, on fostering social cohesion, to garner a more egalitarian distribution of income and to further enhance political stability and medium-term growth, (Furceri and Ostry 2019). By that, it is essential to gauge which sectors in the economy impact inequality and in which way.

Structural change is the long-term change in the sectoral composition of output and employment in a country with implications for income distribution, (Kuznets and Murphy 1966); (Timmer 1988), (Andersson and Chaverra 2015). Although the services sector has taken over agriculture as the main employer, the agricultural sector is central to income distribution in poor countries, where poverty is mostly rural, and unemployment is high. Moreover, manufacturing is seen as the main driver of economic growth. Hence it is important to gauge sector growth on income distribution as sector compositions change across countries.

While measuring the relation between income inequality and various of its determinants such as sector growth, the empirical literature offers a variety of techniques. Cross country regressions, however, suffer from limitations on the standard panel level, including the assumption of a common economic structure across countries whereas substantial differences in the structure production technologies in different sectors as well as policies are intrinsic to each country. Failure to account for country-specific factors may lead to misleading results owing to omitted variables bias, (Herzer and Vollmer 2011). Another methodological short-coming may be that inequality changes may be the result of economic growth, as the Kuznets curve suggests, which some literature may overcome by using instrumental variables albeit it may lead to spurious results when the instruments are weak. Therefore, this paper employs a structural growth perspective to the analysis of income inequality by using heterogeneous panel cointegration methods to gauge the long run impact of the change in sectoral value added as a proxy for structural change on inequality in 43 countries over the period 2003-2017. Heterogeneous panel cointegration methods are robust compared to other estimation techniques in alleviating omitted variables bias, slope heterogeneity and endogenous regressors, (Herzer and Vollmer 2011). Following is a review of some of the valuable insights in the empirical literature on inequality and economic growth.

\section{Literature Review}

Analysis of income inequality has gained much attention from policy-makers around the world, but most of the studies investigate the relationship that runs from 
income inequality to economic growth, whereas there is limited empirical research aiming to capture the effects of sector growth on income inequality. This section highlights on the studies tackling the impact of sector growth on income inequality, in addition to the impact of inflation, unemployment and other macroeconomic factors on income inequality.

\subsection{Impact of sectoral growth on income inequality}

Theoretically, the impact of economic development on inequality remains ambiguous. Theoretical underpinnings of inequality are mostly attributed to the seminal work by, (S. Kuznets 1995), who in his work, found that during the process of economic development, inequality initially increases and then decreases, that is, a widening swing in inequality during the early phases of the transition from preindustrial to industrial civilization is mostly rapid, then stabilizes before it narrows down during the later phases of economic growth. This would entail that while empirically testing this hypothesis, the level of (the log of) GDP per capita and its square are included, (Furceri and Ostry 2019). However, a concern arises while using this approach in time-series is that, while the Gini coefficient (as well as other measures of inequality) are typically bounded and therefore stationary, GDP per capita is not. To overcome this issue, using other bounded (stationary) variables can serve as proxies for development, such as the share of value added in across sectors of the economy. Most developing countries that partially shift from agricultural to industry and/or to services are expected to improve its income distribution by increasing the income of the relatively poor households, (Furceri and Ostry 2019).

Various studies support a positive association between economic growth and inequality, (Rubin and Segal 2015); (Wahiba and Weriemmi 2014); (Lundberg and Squire 2003), while others are in favor of a negative correlation between economic growth and inequality (Bartak and Jabłoński 2020); (Majumdar and Partridge 2009); (Nissim 2007). Further studies have offered mixed results, (Huang, et al. 2015); (Chambers 2010) advocate that variation may have resulted from the use of quantitative tools and the underlying measurement of income inequality. Studies have revealed further that an increase in the value added by the manufacturing sector, can increase the utilization of human capital in these countries, by that, this sector is regarded as a key engine of economic growth, (Kaldor 1967); (Cornwall 1977); (Siami-Namini 2017). Furthermore, the fast- pace growth in the service sector has played key role in the economic growth of developed and emerging market economies, since recently, the service sector accounts for about half of the global trade.

Empirical country studies on factors that determine income inequality were done in several fields. Imai, Gaiha and Cheng, (2016), found that agricultural growth is a major factor in reducing income inequality through direct and indirect effects in China. Bound and Johnson, (1992), and Acemoglu 2002, have studied technological progress as a key factor in labor productivity growth in explaining poverty and income distribution. Dao, (2009) has analysed the impact of human capital components on poverty in 40 developing countries. His study reached that poverty is determined by gender differences in education, child malnutrition and mortality, maternal mortality, and access to prenatal healthcare. Dao, (2009) studied the determinants of rural and national poverty, income distribution, and agricultural growth in developing countries to reach that poverty (those below the 
international poverty line), is influenced by the log of per capita purchasing power parity, gross national income and the region in which individuals are located, and that it linearly depends on per capita agriculture value added. In analysing the relationship between factor endowments, human capital and inequality in 19 developing countries, (Dao 2013) found that cross-country variations in income and consumption may be explained by inequality of investment in human capital as measured by inequality in child health, education and in the distribution of land as measured by the land Gini index.

The change in the intersectoral productivity gap as the measure of structural change and its effect on income inequality in developing countries was estimated by Andersson and Chaverra, (2015) for the period 1960-2010. Results show that show that the inter-sectoral gap has a positive correlation with income inequality whereby $1 \%$ increase in the intersectoral gap increases income inequality by $0.47 \%$. That is, a Gini of 50 declines to 47 in 10 years and 45 in 20 years Andersson and Chaverra, (2015).

\subsection{Impact of inflation \& unemployment on income inequality}

Three main general approaches explain the relationship between inequality and inflation. The first approach by Dornbush and Sebastian, (1989) "macroeconomic populism", indicates that high-income inequality advocates populist policies that intensify political pressure to improve incomes of low-income people through redistribution policy. Theoretically, raising minimum wages may stimulate the economy via increased workers' purchasing power, but on the other hand it may spur adverse effects on employment and force business owners to raise the prices of goods and services, thereby spurring inflation. In turn, inflation puts pressure on real purchasing power by reducing real incomes in the case of a fixed nominal wage, disproportionately affecting lower-income people. Reasons are that poor people do not often have access to passive income, which has a nominal rate positively correlated to inflation. Therefore, a rise in inflation may in the end increase income inequality (Shiller 1996); (Easterly and Stanely 2001).

The second approach is referred to as the "asymmetric war of attrition model," which discusses reasons why countries delay stabilisation owing to existing conflicts between different social and political groups. In this case, income inequality plays a key role in fixing commitment to stabilisation because of political underpinnings that undermine the stability that typically originates from income inequality, (Alberto and Drazen 1991).

The third approach provides a linkage between income inequality and inflation that is based on the "distributive asymmetries of the inflationary process", (Beetsma and Ploeg 1996). That is, it is assumed that when assets are unequally distributed between individuals, the government serves the interests of the poor, by which, it will find hard to fix a policy of low inflation, (Beetsma and Ploeg 1996)

Furthermore, inflation does not impact all types of income sources in the same way (for instance labor-income, capital income, and government transfers), (Monnin 2014). Concerning labor income, inflation can modify earnings via the exposure channel which refers to the wage-inflation link, or through the Cantillon effect which reflects the lag between times when printing money cause inflation because of devaluation of currency. When capital income is concerned, access to financial markets for a security against inflation is not equal between low and high-income people, inducing a positive link between inflation and inequality (Cysne, Maldonado and Monteiro 2005). The impact of 
inflation on government transfers as an income source, depends on the degree of inflation and its persistence. Generally, lower-income groups benefit more from these transfers (Galli and Hoeven 2001).

The trade-off between the unemployment rate and inflation, shown by The Phillips curve, can cause a trade-off between inflation and income inequality. This hypothesis postulates the existence of a nonlinear relationship between inflation and income inequality, Galli and Van Der Hoeven, (2001) show that the long-run relationship between inflation and inequality is " $U$ " Shaped, while some recent empirical evidence shows that inflation reduces income inequality (Bulir and Gulde 1995); (Coibion, et al. 2012).

\subsection{Impact of other macroeconomic factors on income inequality}

On the other hand, several studies have evaluated the distribution effect of fiscal policy on income inequality such as (Afonso 2010); (Doerrenberg 2014); (Wolff 2007). Moreover, (Deaton 2003), (Karahan 2013) and (Coady 2017) showed that social demographic factors were the main determinants of income inequality. Other studies found that globalisation and foreign direct investment impact income inequality levels (Bussmann 2005); (Feenstra 2003); (D. a. Furceri International Monetary Fund, Washington, DC 2015); (Andersson and Chaverra 2015).

In a cross-section study, Furceri and Ostry (2019) found that the level of development, demographics, unemployment and globalisation play key roles in determining inequality. The study finds that trade globalisation is associated with lower inequality levels particularly in developing economies, whereas financial globalisation is associated with higher inequality. Beyond the aforementioned factors, finance and most notably, technology have significantly contributed to the rise in income inequality in many advanced economies (Furceri and Ostry 2019).

The following section entails the empirical investigation of the impact of growth in different sectors of the economy on income inequality across 43 Middle- and Upperincome countries. This section is divided into 4 parts. The first and second parts present the data and the model employed. The third part discusses the methodology adopted in the empirical analysis and the fourth part displays the results.

\section{Data \& Methodology}

This paper employs dynamic panel co-integration technique (with heterogeneous slopes) to regress inequality (GINI coefficient) on sector growth for agriculture, manufacturing, services, as well as on inflation and unemployment, using annual data over the years 2003-2017 across Lower-Middle, Upper-Middle and Upper-income countries.

\subsection{Data}

The choice of countries under study is based on income level as per World Bank classification. However, countries are included according to data availability and are presented in table (A1.1) in Appendix I. The dependent variable is the annual GINI index (World Bank Open Data), as a measurement of income inequality for 43 countries over the period 2003-2017. Figures 1, 2 and 3; present an average of the Gini index for low middle income, high middle income and High-income countries respectively. 


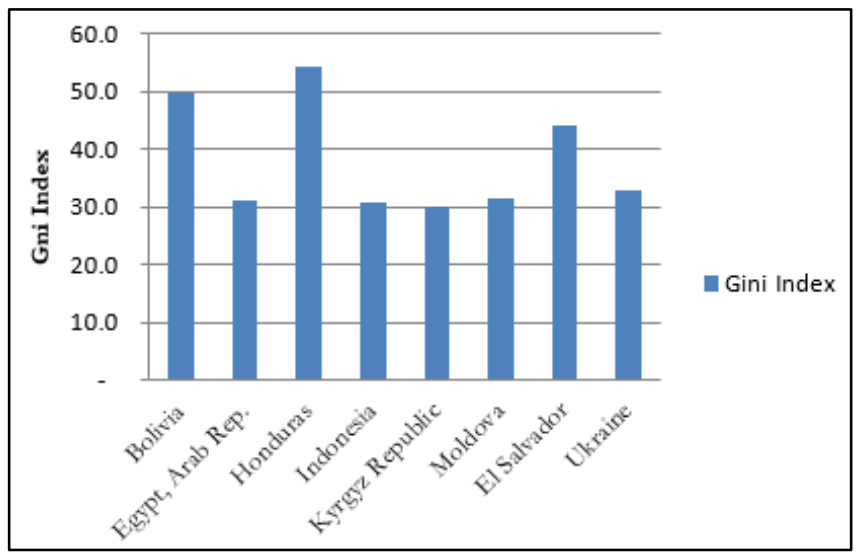

Fig. (1): Gini Index for Low Middle Income Countries: An average for the period 2003-2017

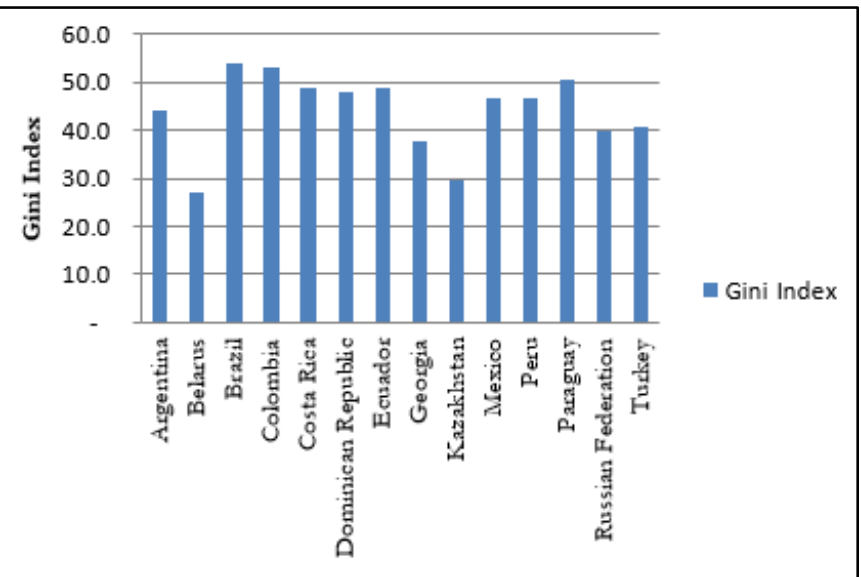

Fig. (2): Gini Index for High Middle Income Countries: An average for the period 2003-2017

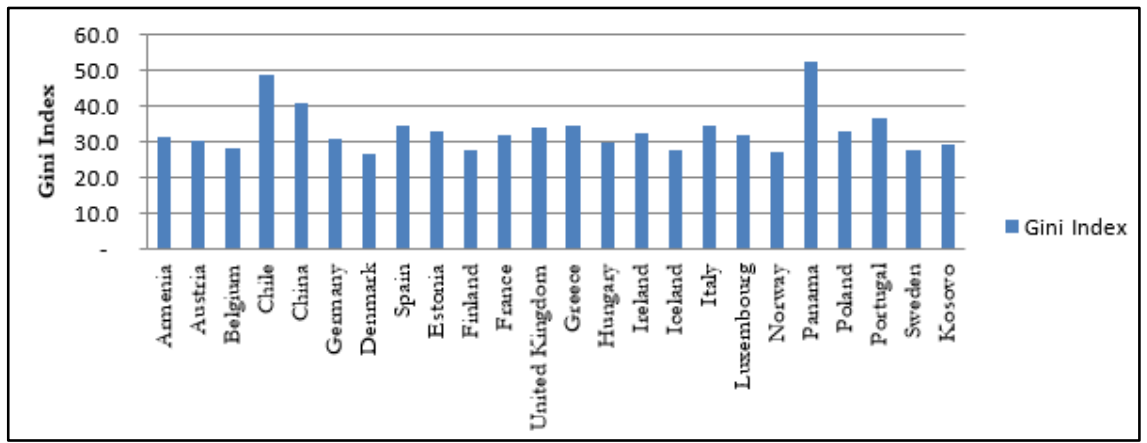

Fig. (3): Gini Index for High Income Countries: An average for the period 2003-2017

The independent variables are annual agriculture value added, (agr), in USD at constant 2010 prices including forestry and fishing. Manufacturing value added, (manuf), in USD at constant 2010 prices, and services, (serv), value added per worker in USD at constant 2010 
prices. Additional controls variables include annual inflation rate (infl) and annual unemployment rate (unempl). Dummy variables are included to represent the different income levels of the countries under study. The source of independent variables is the World Bank Data.

\subsection{Model}

Balanced Panel Analysis for the impact of sector growth on income inequality Gini $_{i t}=f\left(\right.$ agr $\left._{i t}, \operatorname{manuf}_{i t}, \operatorname{serv}_{i t}\right)$

\subsection{Methodology}

\subsubsection{Panel unit root test}

The panel unit root test employed is Im, Pesaran and Shin test. The null hypothesis is that each series in the panel contains a unit root whereas the alternative hypothesis is that at least one of the individual series in the panel is stationary. The test statistic is normally distributed under the null hypothesis and the critical values for the given values of $N$ and $T$ are provided in Im et al. (2003).

\subsubsection{Hausman Specification Test}

Hausman specification test (1978) is employed to decide between the use fixed effects versus random effects.

\subsubsection{Panel Regression Analysis}

This study utilizes two different panel estimation techniques; panel least squares regression and pooled mean group (PMG) estimation of dynamic heterogeneous panels.

\subsubsection{Panel least squares}

Panel Least Squares regression is estimated to gauge the impact of sector growth on income inequality. A quadratic form is estimated as shown in eq(1) to examine the relevance of Kuznets effect. A positive coefficient on $\beta 1$ and negative $\beta 2$ support the Kuznets hypothesis in the agricultural sector. Same applies in both manufacturing sector $\left(\beta_{3}>0, \beta_{4}<0\right)$ and services sector $\left(\beta_{5}>0, \beta_{6}<0\right)$ (Gallup, 2012). GINI $_{i t}=\beta_{0}+\beta_{1}$ Agr $_{i t}+\beta_{2}$ Agr $_{i t}^{2}+\beta_{3}$ Manuf $_{i t}+\beta_{4}$ Manuf $_{i t}^{2}+\beta_{5}$ Serv $_{i t}+$ $\beta_{6}$ Serv $_{i t}^{2}+\beta_{7}$ Infl $_{i t}+\beta_{8}$ Unempl $_{i t}+\sum_{j=1}^{3} \beta_{9 j}$ dummy income level $_{j}+\varepsilon_{i t}$ Eq.(1) where $i$ represents the countries, $t$ represents the time interval, $j$ refers to the income level and $\varepsilon$ refers to the error term.

\subsubsection{Pooled mean group estimation of dynamic heterogeneous panels}

Pooled Mean Group estimation (PMG) is utilized in studies having a large number of cross sections. PMG estimator opposes the classical fixed and random effects in that with intercepts are allowed to differ across groups while error variances remain identical. On the other hand, PMG estimators constrain the long run coefficients to be identical. Yet, allows the short run coefficients and error variances to differ across groups. The estimation of PMG in this study shows the different short run adjustment to be countryspecific, due to the widely different impact of the different macroeconomic conditions and vulnerability of each country to income inequality. PMG is based on Autoregressive 
Distributed Lag Model (ARDL), (Paseran et al, 1999). The generalized form of the PMG estimation is represented by eq (2).

$\Delta Y_{i t}=\theta_{i}\left(y_{i, t-1}-\beta_{i} X_{i, t-1}\right)+\sum_{j=1}^{p} \lambda_{i h} Y_{i, t-j}+\sum_{j=0}^{q} \delta_{i j} X_{i, t-j}+\mu_{i t}+\varepsilon_{i t} \quad$ Eq. (2) where $Y$ is the dependent variable, $X_{i, j}$ represents the independent variables, $\mu_{i}$ represents the fixed- effect; $\varepsilon_{i t}$ represents the vector of standard errors and $\theta_{i}$ is the error correction coefficient. $\beta$ represents the long run parameters, while, , $\lambda_{\mathrm{ij}}$ and $\delta_{\mathrm{ij}}$ represent country specific short-run coefficient vectors. This model is estimated by maximum likelihood estimation.

Economies are divided into four income groups, Low, Lower-middle, Upper-middle, and High, where income is measured in gross national income (GNI) per capita, in U.S. dollars. Income is converted from local currency using the World Bank Atlas method. Countries' classification is determined by two factors, first, countries' GNI per capita, which can change with economic growth, inflation, exchange rates, and population, and second, the classification threshold that is adjusted for inflation annually using the SDR deflator (World Bank, 2019).

Low income countries are excluded from the study owing to the unavailability of the GINI index for all the years under study. Middle-income countries, however, are a very diverse group by region, size, population, and income level, are broken down into Lower middleincome and Upper-middle-income economies. Lower-middle-income economies have a per capita GNI between USD1,026 - 3,995, whereas Upper-middle-income economies have a per capita GNI between USD 3,996 - 12,375. High-income countries are nations with a per capita GNI of more than USD 12,375. (World Bank, 2019).

\section{Results}

\subsection{Pesaran and Shin panel unit root test results}

Panel unit root test has been examined for all the variables under study at their levels and first differences. The results reported in table (1) below show that all the variables are stationary implying that their order of integration is $\mathrm{I}(0)$.

Table 1: Im, Pesaran and Shin Panel Unit Root Test Results

\begin{tabular}{|c|c|c|c|c|c|}
\hline \multirow{2}{*}{ Variable } & \multicolumn{2}{|c|}{ Level } & \multicolumn{2}{|c|}{ First Difference } & \multirow{2}{*}{ Order of integration } \\
\hline & statistic & Prob. & statistic & Prob. & \\
\hline Gini & -3.987 & 0.000 & -11.055 & 0.000 & $\mathrm{I}(0)$ \\
\hline Agr & -3.812 & 0.000 & -10.772 & 0.000 & $\mathrm{I}(0)$ \\
\hline Manuf & -5.858 & 0.000 & -13.087 & 0.000 & $\mathrm{I}(0)$ \\
\hline Serv & -4.381 & 0.000 & -11.869 & 0.000 & $\mathrm{I}(0)$ \\
\hline Inflation rate & -5.583 & 0.000 & -14.147 & 0.000 & $\mathrm{I}(0)$ \\
\hline Unemployment rate & -3.474 & 0.000 & -5.233 & 0.000 & $\mathrm{I}(0)$ \\
\hline
\end{tabular}

\subsection{Hausman Specification Test Results}

Table (2) below shows the results of Hausman test. The test statistic and p-value show that the null hypothesis of using random-effects is rejected implying that the model follows fixed effects. 
Table 2: Hausman Specification Test

\begin{tabular}{|lccc|}
\hline Test Summary & Chi-square statistic & Chi-square degrees of freedom & Prob. \\
Cross-section random & 20.26 & 6 & 0.003 \\
\hline
\end{tabular}

\subsection{Fixed panel least squares regression results}

Table 3: Fixed Panel Least Squares Regression Results

\begin{tabular}{|c|c|c|c|}
\hline & Dep & it Variable: $\mathrm{C}$ & adex \\
\hline & (1) & (2) & (3) \\
\hline Growth Sectors & & & \\
\hline Agr & -0.000 & -0.000 & -0.000 \\
\hline & $(0.000)^{* * *}$ & $(0.000) * * *$ & $(0.000) * * *$ \\
\hline $\operatorname{Agr}^{2}$ & 0.000 & 0.000 & 0.000 \\
\hline & $(0.000) * * *$ & $(0.000) * * *$ & $(0.000) * * *$ \\
\hline Manuf & 0.000 & 0.000 & 0.000 \\
\hline & $(0.001) * *$ & $(0.002) * *$ & $(0.002) * *$ \\
\hline Manuf $^{2}$ & -0.000 & -0.000 & -0.000 \\
\hline & $(0.002) * *$ & $(0.003) * *$ & $(0.003) * *$ \\
\hline Serv & -0.0003 & -0.000 & -0.000 \\
\hline & $(0.000) * * *$ & $(0.000) * * *$ & $(0.000) * * *$ \\
\hline Serv $^{2}$ & 0.000 & ---- & ---- \\
\hline & $(0.000) * * *$ & $(0.000) * * *$ & $(0.000) * * *$ \\
\hline constant & 48.68 & 49.75 & 47.93 \\
\hline & $(0.000) * * *$ & $(0.000) * * *$ & $(0.000) * * *$ \\
\hline Control Variables & & & \\
\hline Inflation rate & 0.042 & 0.042 & 0.042 \\
\hline & $(0.014)^{* *}$ & $(0.014) * *$ & $(0.014) * *$ \\
\hline Unemployment rate & 0.230 & 0.230 & 0.230 \\
\hline & $(0.000) * * *$ & $(0.000) * * *$ & $(0.000) * * *$ \\
\hline Dummy variables & & & \\
\hline High income & & & $\begin{array}{c}2.28 \\
(0.256)\end{array}$ \\
\hline Upper middle income & & $\begin{array}{c}-2.28 \\
(0.256)\end{array}$ & \\
\hline Lower middle income & & $\begin{array}{c}-3.30 \\
(0.098)^{*}\end{array}$ & $\begin{array}{c}-3.30 \\
(0.098)^{*}\end{array}$ \\
\hline Adjusted R-Squared & 0.95 & 0.96 & 0.96 \\
\hline Prob. (F-Statistic) & 0.000 & 0.000 & 0.000 \\
\hline
\end{tabular}

This section addresses the existence of Kuznets hypothesis in line with nonlinear inverted (U shaped) relationship via a fixed panel least squares regression between sector growth (agriculture, manufacturing and services), inflation and unemployment on income inequality, (GINI index). Table (3) above shows the estimation results indicating that sector growth has no impact on income inequality in the long run where all coefficients are statistically significant, and hence it can be deducted no signs of Kuznets effect are evident in this relation. 
Results displayed in table (3) above show a positive relation between inflation and income inequality, indicating that $1 \%$ increase in inflation is expected to increase income inequality by $4.2 \%$. It is expected that inflation erodes real income, thus impacting inequality. Furthermore, unemployment as shown in table (3), indicates a significant and strong correlation with income inequality through a positive coefficient of $23 \%$. Rising unemployment rate results in widening the income gap between those who are employed and those unemployed sections of the population, leading to a rise in inequality. Unemployment may be considered a huge cause of inequality. Country differences may accrue to the variation of unemployment schemes that are designed to support unemployed people, and hence may show variation on country-levels. To capture sector impact growth on inequality more closely, the following section gauges the relationship between sector growth, inflation and unemployment on income inequality on country level, within a heterogeneous panel model.

\subsection{Pooled Mean Group Estimation of Dynamic Heterogeneous Panels}

Pooled mean group estimates for the influence of sector growth on income inequality are reported in Table (4) below, which includes the long-run parameter estimates and the averaged short-run parameter estimates. Yet, the heterogeneous short-run dynamics for each cross-section is reported in Tables 5, 6 and 7 below. The co-efficient of co-integrating equation represents the error correction term, which is negative and significant, implying that around $46.7 \%$ of the deviation from the long-term equilibrium relationship is corrected in the first year.

\section{Table 4: Pooled Mean Group Estimation results}

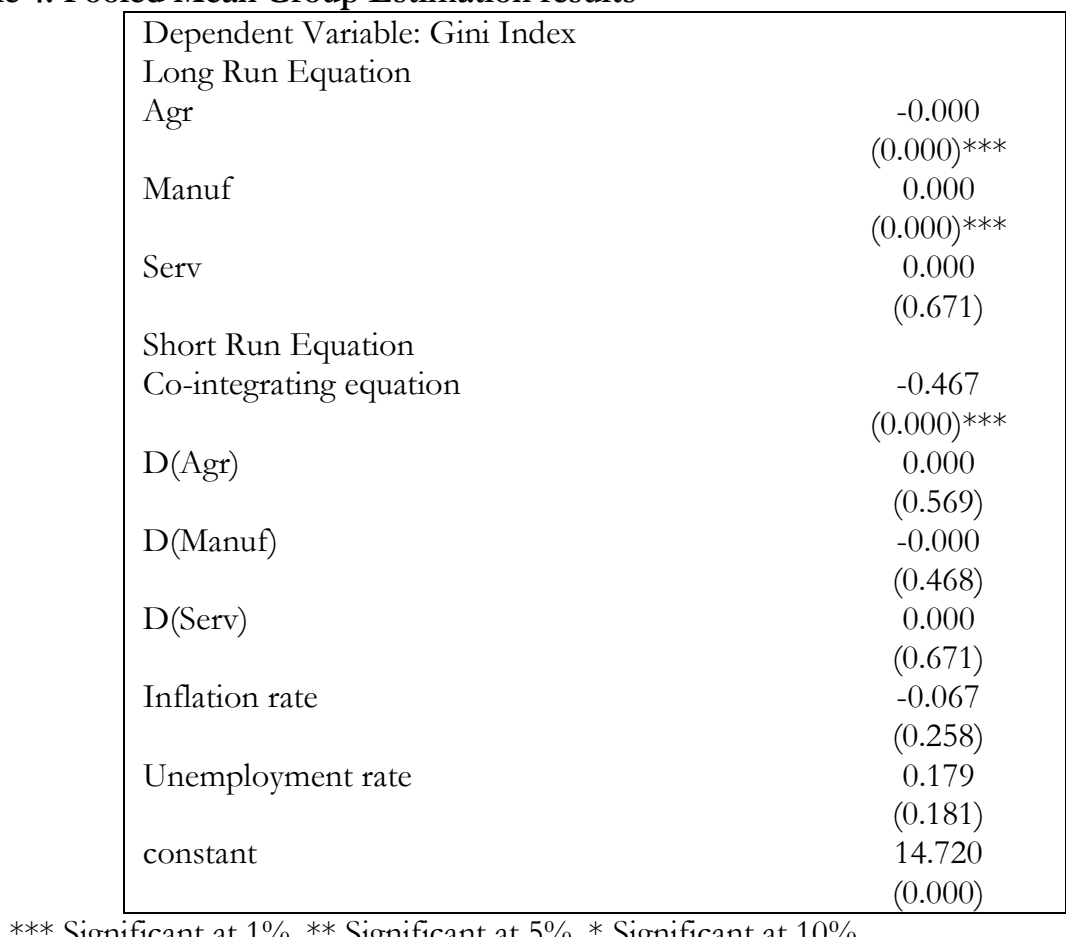


Observing that inequality levels vary greatly among different countries sharing similar levels of development; highlights the importance of national policies and roles that institutions play in tackling inequality, (Alvaredo, et al. 2018). Tables 5, 6 and 7 show results of the heterogeneous short-run dynamics on a country-level where countries are classified according to World Bank income classifications.

Table 5 shows that Lower-Middle Income countries include Bolivia, Egypt, Honduras, Indonesia, Kyrgyz, Moldova, EL Salvador and Ukraine have no sector impact on inequality. Inflation and unemployment have mixed impacts on inequality in Lower middle-income countries, showing insignificant results for Egypt, Indonesia and Kyrgyz Republic. Furthermore, inflation has a negative correlation with inequality in Bolivia, where a $1 \%$ increase in inflation is correlated to $27 \%$ decrease in inequality, whereas unemployment has an insignificant relation with inequality. According to the World Bank, Bolivia's economy grew at an average annual rate of 4.9\% over the decade 2004-2014 owing to the high commodities prices, expansion of natural gas exports and a welldesigned macroeconomic policy resulting in poverty reduction from $59 \%$ to $39 \%$ and the Gini coefficient fell from 0.60 to 0.47 which may explain the correlation between inflation and inequality in the study (https://www.worldbank.org/en/country/bolivia/overview). For the rest of the lower-middle income countries, inflation has a positive correlation with inequality as shown in table 5 above. Honduras has a correlation of $12 \%$ between inflation and inequality, and Honduras' scored the second highest economic growth rate in Central America and high inequality GINI 50.5 in 2017, among the highest in the region and the world (https://www.worldbank.org/en/country/honduras/overview). Unemployment also has a positive correlation of $86 \%$ with inequality showing a very strong correlation. Similarly, results show that Moldova witnesses a positive correlation between inflation and inequality at $21.6 \%$, and inequality has a positive correlation with unemployment at $20.4 \%$ Although Moldova is one of the poorest countries in Europe, it has made significant progress in expanding its economy, propelled by consumption and large-scale outmigration (https://www.worldbank.org/en/country/moldova/overview).

Inflation has a positive influence on inequality in Ukraine with a correlation of $29.5 \%$. Inflation in Ukraine is driven by factors on which monetary policy tools have a limited effect (National Bank ofUkraine 2018) and a positive relation with unemployment at 16\%. Ukraine ranks as the third lowest country in terms of inequality in Europe and Central Asia. Results for El Salvador show that inflation has a significant and positive correlation with inflation of $20.9 \%$ an insignificant correlation with unemployment.

Upper middle-income countries as shown in table (6) below also show negligible to no impact of sector growth on inequality across countries. Also, the impact of both inflation and unemployment vary with country, where inflation shows an insignificant correlation with inequality for Kazakhstan and Turkey. Furthermore, unemployment deems insignificant for Argentina, Belarus, Peru, Paraguay and Russia.

Results in table 6, show that Argentina has a positive correlation between inflation and inequality by that an increase in inflation by $1 \%$ is correlated with increasing inequality by $1.6 \%$, whereas the coefficient for unemployment is insignificant. Brazil shows a positive and significant correlation between inflation and inequality of $17.4 \%$ and a positive and significant correlation for unemployment of $31.3 \%$. Unemployment has a stronger influence on inequality relative to inflation in Brazil. The correlation between inequality 
and inflation in Belarus is weak and significant at $1.3 \%$, while unemployment is insignificant. Colombia has significant results for both inflation and unemployment, showing a positive relation of $5 \%$ between inflation and inequality, and a positive relation of $26 \%$ for unemployment, also revealing the importance of unemployment in determining inequality in Colombia. Costa Rica follows the same pattern as Colombia with positive and significant correlation between inflation and inequality at $19.7 \%$ and a stronger unemployment correlation of $42.1 \%$. The Dominican Republic shows a positive correlation for inflation of $5.4 \%$ and a stronger correlation with unemployment at $42.5 \%$, following the pattern of stronger relation for unemployment over inflation with inequality. Ecuador has a negative and significant relation between inequality and inflation of $45 \%$ and an even higher negative correlation of $81 \%$ for unemployment. Results for Georgia show significance and positive correlations of $13 \%$ and $16 \%$ for inflation and unemployment respectively. Kazakhstan has an insignificant coefficient for inflation and a $427 \%$. Mexico shows a relatively high correlation compared to other members of the same income group with a positive correlation of $63.4 \%$ between inequality and inflation and $81.4 \%$ for unemployment. Peru has a significant negative relation between inequality and inflation of $70.3 \%$ and an insignificant relation between inequality and unemployment. Similarly, Paraguay shows a positive relation for inflation of $24 \%$ and an insignificant relation for unemployment. Russia follows the same pattern albeit with a weaker correlation between inequality and inflation of $4.8 \%$ and insignificant results for unemployment. Turkey has insignificant results for inflation and a positive correlation with inequality for unemployment at $39 \%$.

Hence, it can be concluded that unemployment has a stronger influence on inequality relative to inflation for Upper-middle income countries, unlike in Lower-middle income countries, with the exception of Honduras. Overall, results show that Unemployment's correlation with inequality is not stronger than inflation.

Table (5) shows results for High-income countries. Results show no sectoral impact on inequality similar to Middle-income countries. However, inflation and unemployment show significant influence on inequality. The differential influence between inflation and unemployment is not as big as in Upper middle-income countries overall, with the exception of Belgium. Results show that inflation has a significant and negative correlation with inequality in Austria of $49 \%$ while unemployment has a significant and negative impact of $52 \%$. Inflation in Belgium has a negative correlation with inequality and a higher negative impact of unemployment on inequality at $75 \%$. Belgium is the only country in this income group with a higher discrepancy between the influence of inflation and unemployment. Chile shows insignificant results for inflation and unemployment on inequality. Results for Germany show a negative correlation between inflation and inequality at 35\% while inflation has a lower negative correlation with inequality at $11 \%$. The correlation between inequality and inflation in Denmark shows insignificant results while unemployment has a positive correlation of $9 \%$. The correlation between inequality and inflation is a relatively lower in Spain than countries of the similar income level, at $0.9 \%$ also unemployment has a negligible impact on inequality of $0.1 \%$. Estonia has a positive impact between inflation and inequality of $12 \%$ as well as a positive impact of unemployment on inequality of $10.6 \%$. Finland also shows relatively lower impacts of inflation and unemployment on inequality. However, inflation shows a negative coefficient 
of $5.8 \%$ while unemployment has a positive relation with inequality of $3.5 \%$ respectively. France has both coefficients negatively and more strongly correlated with inequality, at $18.7 \%$ for inflation and $49.3 \%$ for unemployment. The United Kingdom has a significant and negative coefficient of $22.9 \%$ for the influence of inflation on inequality while an insignificant coefficient for unemployment. Hungary has an insignificant result for inflation and a positive correlation between inequality and unemployment of $34.8 \%$. Greece has a positive correlation with inflation of $8.2 \%$ and a small influence of unemployment on inequality of $0.3 \%$. Ireland has a negative relation between inequality and inflation of $20.6 \%$ and insignificant results for unemployment. While, Iceland has a $17.5 \%$ correlation between inflation and inequality and a negative $51.8 \%$ for unemployment. Italy results show $29.2 \%$ positive correlation for inflation and a relatively lower positive correlation for unemployment of $6.2 \%$. Luxemburg has a relatively strong correlation between inequality and inflation at a positive $106 \%$ while unemployment is a positive $39.6 \%$. Panama results show that the influence of inflation on inequality is a positive $4.6 \%$ while unemployment is insignificant. Poland has $11.6 \%$ positive correlation with inequality and a weaker relation for unemployment of $0.6 \%$. Norway, similar to Luxemburg, has a strong correlation between inequality and inflation at a negative 164\% and a stronger positive correlation for unemployment of $173 \%$. This relation is the strongest in the results for the impact of the determinants on inequality. Portugal shows a positive correlation for both determinants on inequality, of $17 \%$ for inflation and $3.9 \%$ for unemployment, and Sweden has insignificant results for inflation and a positive correlation between inequality and unemployment of $17 \%$.

Table 5: Results of Short Run Co-integration Coefficients: Low Middle-Income Countries

\begin{tabular}{|lccccccc|}
\hline Country & Variable & COINTEQ01 & D(Agr) & D(MAnuf) & D(Serv) & Inflation rate & Unemployment \\
Bolivia & Co-efficient & 0.0907 & 0.0000 & 0.0000 & 0.0011 & -0.2714 & -0.9019 \\
& Prob. & $0.0007^{* * *}$ & $0.0000^{* * *}$ & $0.0000^{* * *}$ & $0.0000^{* * *}$ & $0.0018^{* * *}$ & 0.5232 \\
Egypt & Co-efficient & -0.2168 & 0.0000 & 0.0000 & 0.0012 & -0.0083 & -0.0308 \\
& Prob. & $0.0002^{* * *}$ & $0.0000^{* * *}$ & $0.0000^{* * *}$ & $0.0000^{* * *}$ & 0.2828 & 0.5391 \\
Honduras & Co-efficient & -0.1079 & 0.0000 & 0.0000 & 0.0029 & 0.1215 & 0.8672 \\
& Prob. & $0.0000^{* * *}$ & $0.0000^{* * *}$ & $0.0000^{* * *}$ & $0.0000^{* * *}$ & $0.0565^{*}$ & $0.0205^{*}$ \\
Indonesia & Co-efficient & -0.0338 & 0.0000 & 0.0000 & 0.0000 & -0.0157 & 0.1904 \\
& Prob. & 0.4128 & $0.0000^{* * *}$ & $0.0000^{* * *}$ & $0.0015^{* * *}$ & 0.3605 & 0.1539 \\
Kyrgyz Republic & Co-efficient & -0.0338 & 0.0000 & 0.0000 & 0.0000 & -0.0157 & 0.1904 \\
& Prob. & 0.4128 & $0.0000^{* * *}$ & $0.0000^{* * *}$ & $0.0015^{* * *}$ & 0.3605 & 0.1539 \\
Moldova & Co-efficient & -0.1292 & 0.0000 & 0.0000 & 0.0009 & 0.2162 & 0.2045 \\
& Prob. & $0.0000^{* * *}$ & $0.0000^{* * *}$ & $0.0000^{* * *}$ & $0.0000^{* * *}$ & $0.0000^{* * *}$ & $0.0014^{* * *}$ \\
Ukraine & Co-efficient & -0.0916 & 0.0000 & 0.0000 & -0.0001 & 0.0295 & 0.1607 \\
& Prob. & $0.0002^{* * *}$ & $0.0000^{* * *}$ & $0.0000^{* * *}$ & $0.0000^{* * *}$ & $0.0000^{* * *}$ & $0.0112^{* *}$ \\
El Salvador & Co-efficient & -0.0199 & 0.0000 & 0.0000 & -0.0049 & 0.2093 & -0.0898 \\
& Prob. & $0.0063^{* * *}$ & $0.0000^{* * *}$ & $0.0000^{* * *}$ & $0.0000^{* * *}$ & $0.0065^{* * *}$ & 0.6615 \\
\hline
\end{tabular}

*** Significant at $1 \%$, ** Significant at $5 \%$, $*$ Significant at $10 \%$

Table 6: Results of Short Run Co-integration Co-efficients: Upper Middle-Income Countries

\begin{tabular}{|lccccccc|}
\hline Country & Variable & COINTEQ01 & D(Agr) & D(MAnuf) & D(Serv) & Inflation rate Unemployment \\
Argentina & Co-efficient & -0.037 & 0.000 & 0.000 & 0.001 & 0.016 & 0.022 \\
& Prob. & $0.003^{* * *}$ & $0.000^{* * *}$ & $0.000^{* * *}$ & $0.000^{* * *}$ & $0.000^{* * *}$ & 0.600 \\
Brazil & Co-efficient & -0.114 & 0.000 & 0.000 & 0.000 & 0.174 & 0.313 \\
& Prob. & $0.000^{* * *}$ & $0.000^{* * *}$ & $0.000^{* * *}$ & $0.000^{* * *}$ & $0.000^{* * *}$ & $0.000^{* * *}$ \\
Belarus & Co-efficient & 0.003 & 0.000 & 0.000 & -0.001 & -0.013 & 0.050 \\
& Prob. & 0.691 & $0.000^{* * *}$ & $0.000^{* * *}$ & $0.000^{* * *}$ & $0.000^{* * *}$ & 0.535 \\
\hline
\end{tabular}




\begin{tabular}{|c|c|c|c|c|c|c|c|}
\hline Country & Variable & COINTEQ01 & D(Agr) & D(MAnuf) & $\mathrm{D}$ (Serv) & Inflation rate & Unemployment \\
\hline \multirow[t]{2}{*}{ Colombia } & Co-efficient & -0.068 & 0.000 & 0.000 & 0.002 & 0.051 & 0.260 \\
\hline & Prob. & $0.000 * * *$ & $0.000 * * *$ & $0.000^{* * *}$ & $0.000 * * *$ & $0.070^{*}$ & $0.009 * * *$ \\
\hline \multirow[t]{2}{*}{ Costa Rica } & Co-efficient & -0.125 & 0.000 & 0.000 & 0.000 & 0.197 & 0.421 \\
\hline & Prob. & $0.000 * * *$ & $0.000 * * *$ & $0.000^{* * *}$ & $0.000 * * *$ & $0.000 * * *$ & $0.001 * * *$ \\
\hline \multirow[t]{2}{*}{ Dominic Republic } & Co-efficient & -0.069 & 0.000 & 0.000 & -0.004 & 0.054 & 0.425 \\
\hline & Prob. & $0.000 * * *$ & $0.000^{* * *}$ & $0.000^{* * *}$ & $0.000 * * *$ & $0.000 * * *$ & $0.004 * * *$ \\
\hline \multirow[t]{2}{*}{ Ecuador } & Co-efficient & 0.123 & 0.000 & 0.000 & 0.000 & -0.451 & -0.810 \\
\hline & Prob. & $0.000 * * *$ & $0.000 * * *$ & $0.000^{* * *}$ & $0.000^{* * *}$ & $0.001 * * *$ & $0.063^{*}$ \\
\hline \multirow[t]{2}{*}{ Georgia } & Co-efficient & -0.101 & 0.000 & 0.000 & 0.000 & 0.136 & 0.161 \\
\hline & Prob. & $0.000 * * *$ & $0.000 * * *$ & $0.000^{* * *}$ & $0.000^{* * *}$ & $0.000^{* * *}$ & $0.001 * * *$ \\
\hline \multirow[t]{2}{*}{ Kazakhstan } & Co-efficient & -1.340 & 0.000 & 0.000 & -0.001 & -0.033 & 4.279 \\
\hline & Prob. & $0.001 * * *$ & $0.000 * * *$ & $0.000^{* * *}$ & $0.000^{* * *}$ & 0.349 & $0.017^{* *}$ \\
\hline \multirow[t]{2}{*}{ Mexico } & Co-efficient & -0.205 & 0.000 & 0.000 & -0.002 & 0.634 & 0.814 \\
\hline & Prob. & $0.000 * * *$ & $0.000 * * *$ & $0.000^{* * *}$ & $0.000 * * *$ & $0.073^{*}$ & $0.066^{*}$ \\
\hline \multirow[t]{2}{*}{ Peru } & Co-efficient & 0.039 & 0.000 & 0.000 & 0.001 & -0.703 & -0.173 \\
\hline & Prob. & $0.001 * * *$ & $0.000 * * *$ & $0.000^{* * *}$ & $0.000 * * *$ & $0.000^{* * *}$ & 0.600 \\
\hline \multirow[t]{2}{*}{ Paraguay } & Co-efficient & -0.064 & 0.000 & 0.000 & 0.005 & 0.240 & 0.056 \\
\hline & Prob. & $0.001 * * *$ & $0.000 * * *$ & $0.000^{* * *}$ & $0.000 * * *$ & $0.001 * * *$ & 0.894 \\
\hline \multirow[t]{2}{*}{ Russian Federation } & Co-efficient & -0.059 & 0.000 & 0.000 & 0.001 & -0.048 & 0.213 \\
\hline & Prob. & $0.006 * * *$ & $0.000 * * *$ & $0.000^{* * *}$ & $0.000 * * *$ & $0.005^{* * *}$ & 0.197 \\
\hline \multirow[t]{2}{*}{ Turkey } & Co-efficient & -0.308 & 0.000 & 0.000 & 0.000 & -0.004 & 0.391 \\
\hline & Prob. & $0.000 * * *$ & $0.000 * * *$ & $0.000^{* * *}$ & $0.000 * * *$ & 0.853 & $0.001 * * *$ \\
\hline
\end{tabular}

*** Significant at $1 \%$, ** Significant at $5 \%$, * Significant at $10 \%$

Table 7: Results of Short Run Co-integration Coefficients: High-Income Countries

\begin{tabular}{|c|c|c|c|c|c|c|c|}
\hline Country & Variable & COINTEQ01 & D(Agr) & D(MAnuf) & D(Serv) & Inflation rate & Unemployment \\
\hline \multirow[t]{2}{*}{ Austria } & Co-efficient & -0.373 & 0.000 & 0.000 & 0.000 & -0.491 & -0.521 \\
\hline & Prob. & $0.000 * * *$ & $0.000^{* * *}$ & $0.000^{* * *}$ & $0.000^{* * *}$ & $0.000^{* * *}$ & $0.000 * * *$ \\
\hline \multirow[t]{2}{*}{ Belguim } & Co-efficient & -0.393 & 0.000 & 0.000 & 0.000 & -0.423 & -0.758 \\
\hline & Prob. & $0.000^{* * *}$ & $0.000^{* * *}$ & $0.000^{* * *}$ & $0.000^{* * *}$ & $0.000^{* * *}$ & $0.001 * * *$ \\
\hline \multirow[t]{2}{*}{ Chile } & Co-efficient & -0.011 & 0.000 & 0.000 & 0.000 & 0.016 & 0.044 \\
\hline & Prob. & $0.023^{* *}$ & $0.000 * * *$ & $0.000^{* * *}$ & $0.000^{* * *}$ & 0.339 & 0.386 \\
\hline \multirow{2}{*}{ Germany } & Co-efficient & -0.242 & 0.000 & 0.000 & 0.000 & -0.355 & -0.118 \\
\hline & Prob. & $0.000^{* * *}$ & $0.000^{* * *}$ & $0.000^{* * *}$ & $0.000^{* * *}$ & $0.002^{* * *}$ & $0.002^{* * *}$ \\
\hline \multirow[t]{2}{*}{ Denmark } & Co-efficient & 0.016 & 0.000 & 0.000 & 0.000 & 0.024 & 0.095 \\
\hline & Prob. & $0.001 * * *$ & $0.000 * * *$ & $0.000^{* * *}$ & $0.000 * * *$ & 0.398 & $0.002^{* * *}$ \\
\hline \multirow[t]{2}{*}{ Spain } & Co-efficient & -0.630 & 0.000 & 0.000 & 0.000 & 0.009 & -0.001 \\
\hline & Prob. & $0.000 * * *$ & $0.000 * * *$ & $0.000^{* * *}$ & $0.000 * * *$ & $0.013^{* *}$ & $0.010^{* * *}$ \\
\hline \multirow[t]{2}{*}{ Estonia } & Co-efficient & -0.086 & 0.000 & 0.000 & -0.001 & 0.120 & 0.106 \\
\hline & Prob. & $0.000^{* * *}$ & $0.000 * * *$ & $0.000^{* * *}$ & $0.000^{* * *}$ & $0.000^{* * *}$ & $0.000^{* * *}$ \\
\hline \multirow[t]{2}{*}{ Finland } & Co-efficient & 0.029 & 0.000 & 0.000 & 0.000 & -0.058 & 0.035 \\
\hline & Prob. & $0.039 * *$ & $0.000 * * *$ & $0.000^{* * *}$ & 0.000 & $0.003^{* * *}$ & $0.056^{*}$ \\
\hline \multirow[t]{2}{*}{ France } & Co-efficient & -0.326 & 0.000 & 0.000 & 0.000 & -0.187 & -0.493 \\
\hline & Prob. & $0.000^{* * *}$ & $0.000 * * *$ & $0.000^{* * *}$ & $0.000^{* * *}$ & $0.034^{* *}$ & $0.001 * * *$ \\
\hline \multirow[t]{2}{*}{ United Kingdom } & Co-efficient & -0.160 & 0.000 & 0.000 & 0.000 & -0.229 & 0.011 \\
\hline & Prob. & $0.001 * * *$ & $0.000 * * *$ & $0.000^{* * *}$ & $0.000 * * *$ & $0.035^{* *}$ & 0.399 \\
\hline \multirow[t]{2}{*}{ Hungary } & Co-efficient & -0.190 & 0.000 & 0.000 & 0.000 & 0.002 & 0.348 \\
\hline & Prob. & $0.003^{* * *}$ & $0.000^{* * *}$ & $0.000^{* * *}$ & $0.020^{* *}$ & 0.977 & $0.027^{* *}$ \\
\hline \multirow[t]{2}{*}{ Greece } & Co-efficient & 0.053 & 0.000 & 0.000 & 0.000 & 0.082 & -0.003 \\
\hline & Prob. & $0.133^{* *}$ & $0.000^{* * *}$ & $0.000^{* * *}$ & $0.000^{* * *}$ & $0.001 * * *$ & $0.024 * *$ \\
\hline \multirow[t]{2}{*}{ Ireland } & Co-efficient & -0.005 & 0.000 & 0.000 & 0.000 & -0.206 & 0.001 \\
\hline & Prob. & $0.005^{* * *}$ & $0.000^{* * *}$ & $0.000^{* * *}$ & $0.000^{* * *}$ & $0.000^{* * *}$ & 0.485 \\
\hline \multirow[t]{2}{*}{ Iceland } & Co-efficient & -1.025 & 0.000 & 0.000 & 0.000 & 0.175 & -0.518 \\
\hline & Prob. & $0.000^{* * *}$ & $0.000^{* * *}$ & $0.000^{* * *}$ & $0.000^{* * *}$ & $0.000^{* * *}$ & $0.000^{* * *}$ \\
\hline \multirow[t]{2}{*}{ Italy } & Co-efficient & 0.075 & 0.000 & 0.000 & 0.000 & 0.292 & 0.062 \\
\hline & Prob. & $0.000^{* * *}$ & $0.000 * * *$ & $0.000^{* * *}$ & $0.000^{* * *}$ & $0.004^{* * *}$ & $0.000^{* * *}$ \\
\hline \multirow[t]{2}{*}{ Luxembourg } & Co-efficient & 0.055 & 0.000 & 0.000 & 0.000 & 1.066 & 0.396 \\
\hline & Prob. & $0.000^{* * *}$ & $0.000^{* * *}$ & $0.000^{* * *}$ & $0.000^{* * *}$ & $0.018^{* *}$ & $0.077^{*}$ \\
\hline \multirow[t]{2}{*}{ Panama } & Co-efficient & -0.030 & 0.000 & 0.000 & 0.000 & 0.046 & 0.146 \\
\hline & Prob. & $0.001 * * *$ & $0.000 * * *$ & $0.000 * * *$ & $0.000 * * *$ & $0.066^{*}$ & 0.541 \\
\hline
\end{tabular}




\begin{tabular}{|lccccccc|}
\hline Country & Variable & COINTEQ01 & D(Agr) & D(MAnuf) & D(Serv) & Inflation rate & Unemployment \\
Poland & Co-efficient & -0.043 & 0.000 & 0.000 & 0.000 & 0.116 & 0.006 \\
& Prob. & $0.000^{* * *}$ & $0.000^{* * *}$ & $0.000^{* * *}$ & $0.000^{* * *}$ & $0.000^{* * *}$ & $0.007^{* * *}$ \\
Norway & Co-efficient & 0.031 & 0.000 & 0.000 & -0.001 & -1.644 & 1.737 \\
& Prob. & $0.001^{* * *}$ & $0.000^{* * *}$ & $0.000^{* * *}$ & $0.000^{* * *}$ & $0.001 * * *$ & $0.005^{* * *}$ \\
Portugal & Co-efficient & -0.076 & 0.000 & 0.000 & 0.000 & 0.170 & 0.039 \\
& Prob. & $0.000^{* * *}$ & $0.000^{* * *}$ & $0.000^{* * *}$ & $0.000^{* * *}$ & $0.000^{* * *}$ & $0.000^{* * *}$ \\
Sweden & Co-efficient & -0.107 & 0.000 & 0.000 & 0.000 & 0.060 & -0.170 \\
& Prob. & $0.001^{* * *}$ & $0.000^{* * *}$ & $0.000^{* * *}$ & $0.000^{* * *}$ & 0.116 & $0.003^{* * *}$ \\
\hline
\end{tabular}

\section{Conclusion}

The study gauged the impact of sector growth, inflation and unemployment on inequality in 43 Middle-and Upper Income countries owing to the importance of sectoral growth on income distribution patterns and in an attempt to show which sectors contribute more to impacting income inequality. Results show that across all countries, sector growth had no to negligible impact on inequality. However, both inflation and unemployment have mixed impacts on inequality in Lower and Middle-Income countries. Results further show that unemployment has a relatively stronger influence on inequality than inflation for Upper-middle income countries, unlike in Lower-middle income countries, where unemployment shows a weaker correlation than inflation. Results for High-income countries reveal that the influence between inflation and unemployment are not as big as in Upper middle-income countries overall. Results may imply that macroeconomic policies especially those related to unemployment may have influence on inequality since unemployment seems to be the relatively dominant determinant factor in the relation under study relative to sector growth and inflation.

\section{References}

Acemoglu, D. 2002. "Technical change, inequality, and the labor market." Journal of Economic Literature Vol. 40 No. 1, pp. 7-72.

Afonso, A., Schuknecht, L. and Tanzi, V. 2010. "'Income distribution and public spending: an efficiency assessment." The Journal of Economic Inequality Vol. 8 No. 3, pp. 367-389.

Alberto, Alesina, and Allan Drazen. 1991. "Why Are Stabilisations Delayed?" American Economic Revien vol.81,(\%),1170-88.

Alesina, A., and D.Rodrik. 1994. "Distributive Politics and Economic Growth ." Q. J. Econ 109, 465-490.

Alvaredo, Facundo, Lucas Chancel, Thomas Piketty, Emmanuel Saez, and Gabriel Zucman. 2018. "World inequality report."

Andersson, Martin P., and Andrés F. Palacio Chaverra. 2015. "Structural change and income inequality Agricultural development and inter-sectoral dualism in the developing world, 1960-2010." Oasis 23, 99-122.

Bartak, J. and Jabłoński, L. 2020. "Inequality and growth: What comes from the different inequality measures?" Bull Econ Res. Vol.72, pp.185-212.

Beetsma, Roel M.W., and Frederick Van Der Ploeg. 1996. "Does Inequality cause Inflation?: The Political economy of inflation, taxation and government debt." Public Choice Vol. 87:1-2,143-162.

Bound, J., and G. Johnson. 1992. "Changes in the structure of wages during the 1980s: an evaluation of alternative explanations." American Economic Review Vol. 82 No. 3, pp. 371-392.

Bulir, Ales, and Anne-Marie Gulde. 1995. "Inflation and Income Distribution: Further Evidence on Empirical Links." IMF Working Paper 1-30.

Bussmann, M., De Soysa, I. and Oneal, J.R. 2005. "The effect of globalization on national income inequality." Comparative Sociology Vol. 4 No. 3, pp. 285-312. 
Chambers, Dustin. 2010. "Does a rising tide raise all ships? The impact of growth on inequality ." Applied Economics Letters 17: 581-86.

Coady, D. and Dizioli, A. 2017. "Income inequality and education revisited: persistence, endogeneity and heterogeneity." IMF working paper 17/126 International Monetary Fund, Washington, DC.

Coibion, Olivier, Yuriy Gorodnichenko, Lorenz Kueng, and John Silvia. 2012. "Innocent Bystanders?Monetary Policy and Inequality in the U.S." IZA Discussion Paper No. 6633 .

Cornwall, J. 1977. Modern Capitalism: Its Growth and Transformation, Martin Robertson,. London.: Martin Robertson.

Cysne, Rubens P., Wilfredo L. Maldonado, and Paulo Kilnger Monteiro. 2005. "Inflation and Income inequality: A shopping-time approach." Journal of Development Economics Vol:78, 516-528.

Dao, M.Q. 2013. "'Factor endowment, human capital, and inequality in developing countries"." Journal of Economic Studeis Vol. 40 No. 1, pp. 98-106.

Dao, M.Q. 2009. "Human capital, poverty, and income distribution in developing countries." Journal of Economic Studies Vol. 36 No. 2, pp. 168-183.

Deaton, A. 2003. "Health, inequality, and economic development." Journal of Economic Literature Vol. 41 No. 1, pp. 113-158.

Doerrenberg, P. and Peichl, A. 2014. "The impact of redistributive policies on inequality in OECD countries." Applied Economics Vol. 46 No. 17, pp. 2066-2086.

Dornbush, Rudiger, and Edwards Sebastian. 1989. The Macroeconomics of Populism in Latin America. Policy, Planning and Research Department working papers; no WPS 316, Washington: World Bank.

Easterly, William, and Fischer Stanely. 2001. "Inflation and the Poor." Journal of Money, Credit and Banking, Blackwell Publishing vol.33(2),160-178 May.

Feenstra, R. and Hanson, G. (2003). 2003. "Global production sharing and rising inequality: a survey of trade and wages." In Handbook of International Trade, by E.K. and Harrigan, J. (Eds) Choi, pp. 146-185. Malden, MA: Blackwell.

Furceri, D. and Loungani, P. International Monetary Fund, Washington, DC 2015. "Capital account liberalization and inequality." IMF Working Paper No. WP/15/243.

Furceri, Davide, and Jonathan D. Ostry. 2019. "Robust determinants of income inequality." Oxford Review of Economic Policy Volume 35,490-517.

Galli, Rossana, and Rolph van Der Hoeven. 2001. "Is Inflation bad for Income inequality: The importance of the initial rate of inflation." ILO.

Gallup, John Luke. 2012. "Is There a Kuznets Curve?" Portland State University.

Hausman, J. A. 1978. "“Specification Tests in Econometrics."." Econometrica vol. 46, no. 6, 1978, pp. $1251-$ 1271.

Herzer, Dierk, and Sebastian Vollmer. 2011. "Inequality and growth: evidence from panel." Journal of Economic Inequality 10:489-503.

n.d. "https://data.worldbank.org/."

Huang, Ho Chuan, WenShwo Fang, Stephen M. Miller, and Chih-Chuan Yeh. 2015. "The effect of growth volatility on income inequality ." Economic Modelling 45: 212-22.

Im, Kyung So, and M Pesaran and Yongcheol Shin. 2003. " Testing for unit roots in heterogeneous panels." Journal of Econometrics 115, (1), 53-74.

Imai, K.S., R. Gaiha, and W. Cheng. 2016. "Does agricultural growth reduce inequality and poverty in developing countries?" Research institute for economics and business administration, Kobe University DP201523.

Kaldor, N. 1967. Strategic Factor in Economic Development. New York : New York State School of Industrial and Labor Relations, New York, NY., New York, NY.

Kanbur, R., C. Rhee, and J. (eds.) Zhuang. 2014. Inequality In Asia and the Pacific: Trends, drivers, and policy implications. New York: Routledge.

Karahan, F. and Ozkan, S. (2013). 2013. "On the persistence of income shocks over the life cycle: evidence theory, and implications." Review of Economic Dynamics Vol. 16 No. 3, pp. 452-476.

Kuznets, S., and J. T. Murphy. 1966. Modern economic growth: Rate, structure, and spread. New Haven : Yale University Press.

Kuznets, Simon. 1995. "Economic Growth and Income Inequality." American Economic Review 45: 1-28.

Lundberg, Mattias, and Lyn Squire. 2003. "The simultaneous evolution of growth and inequality." The Economic Journal 113: 326-44. 
Lustig, N., Lopez-Calva, L. F. y Ortiz-Juarez, and E. 2013. "Declining inequality in Latin America in the 2000s: the cases of Argentina, Brazil, and Mexico." World Development 44, 129-141.

Majumdar, Shibalee, and Mark D. Partridge. 2009. "Impact of economic growth on income inequality: A regional perspective." Agricultural and Applied Economics Association. Milwaukee, WI, USA,.

Monnin, Pierre. 2014. "Inflation and Income Inequality in Developing Countries ." CEP Working Paper Series 2014/1.

National Bank ofUkraine. 2018. "Inflation Report."

Nissim, Ben-David. 2007. "Economic growth and its effect on income distribution." Journal of Economic Studies 34:42-58.

Pesaran, M. Hashem, et al. 1999. "Pooled Mean Group Estimation of Dynamic Heterogeneous Panels." Journal of the American Statistical Association vol. 94, no. 446, 1999, pp. 621-634.

Rubin, Amir, and Dan Segal. 2015. "The effects of economic growth on income inequality in the US." Journal of Macroeconomics 45: 258-73.

Shiller, Robert J. 1996. "Why DO People Dislike Inflaiton?" NBER (NBER) WP 5539.

Siami-Namini, S. 2017. "Granger causality between gross domestic product and economic sectors in developing countries: a panel co-integration approach." International Journal of Economics and Financial Issues Vol. 7 No. 5, pp. 53-58.

Thorbecke, E.,, and S. Duyang. 2016. Is Sub-Saharan Africa Finally Catching up? In: Development Paths and Structural Transformation in the Escape from Poverty. New York: Oxford University Press.

Timmer, C. P. 1988. "The agricultural transformation." Handbook of development economics 1 (Part II) 276-331.

Vo, Duc Hong, Thang Cong Nguyen, Ngoc Phu Tran, and Anh The Vo. 2019. "What Factors Affect Income Inequality and Economic Growth in Middle-Income Countries?" J. Risk Financial Management 12, 40.

Wahiba, Nasfi Fkili, and Malek El Weriemmi. 2014. "The Relationship Between Economic Growth and Income Inequality." International Journal of Economics and Financial Issues 4: 135-43.

Wolff, E. and Zacharias, A. 2007. "The distributional consequences of government spending and taxation in the U.S. 1989 and 2000." Review of Income and Wealth Vol. 53 No. 4,pp. 692-715.

World Bank Indicators, https://www.worldbank.org/en/country/bolivia/overview).

World Bank Indicators, (https://www.worldbank.org/en/country/honduras/overview).

World Bank Indicators, (https://www.worldbank.org/en/country/moldova/overview).

\section{Appendix}

\section{Appendix I: List of countries}

Table (A1.1): List of countries under study classified by income level according to World Bank country classification

\begin{tabular}{|l|l|l|l|l|}
\hline $\begin{array}{l}\text { Lower Middle-Income } \\
\text { countries }\end{array}$ & $\begin{array}{l}\text { Upper middle } \\
\text { countries }\end{array}$ & $\begin{array}{l}\text { High Income } \\
\text { countries }\end{array}$ \\
\hline Bolivia & Argentina & Georgia & Austria & Italy \\
\hline Egypt & Belarus & Kazakhstan & Belgium & Luxembourg \\
\hline Honduras & Brazil & Mexico & Chile & Panama \\
\hline Indonesia & Colombia & Peru & Germany & Poland \\
\hline Kyrgyz & Costa Rica & Paraguay & Denmark & Portugal \\
\hline Moldova & Dominican Republic & Russian Federation & Spain & Sweden \\
\hline El Salvador & \multirow{2}{*}{ Ecuador } & \multirow{2}{*}{ Turkey } & Estonia & Norway \\
\hline Ukraine & & Finland & Hungary \\
\hline & & France & Ireland \\
\hline & & United Kingdom & Iceland \\
\cline { 5 - 5 } & & Greece & \\
\hline
\end{tabular}

